\title{
Consumer health information services in public libraries in Canada and the US
}

\author{
Susan Murray
}

\begin{abstract}
In response to a growing demand from the public for health information resources, North American public libraries have provided varying levels of consumer health information (CHI) services since the 1970s. Due to the availability of funding in the US, many American public libraries have provided CHI services, although the majority of these have been as partnerships with health sciences libraries or via the "Go Local" programs. In Canada, where no specific funding has been available for CHI services, few public libraries have set up CHI services; health information has generally been provided by augmenting health collections or "virtually," i.e., by providing links to recommended electronic resources via the library's Web site.
\end{abstract}

\section{Consumer health movement}

The demand for consumer health information (CHI) is not a recent phenomenon. Following on the heels of the 1960s consumer movement in the US was the women's health movement in the 1970s and 1980s. Feminist publications such as Our Bodies Ourselves and Healthsharing encouraged women to become active participants in their health care and spearheaded the health consumer movement in North America [1].

\section{Trends in health information}

There has been a growing demand for health information from the public. In the 1990 survey of Ontario public libraries, "typically from 5 to 10 percent of all questions at a public library reference desk involve consumer health" [2]. A sample of US public libraries conducted in the late 1990s found that as many as $20 \%$ of reference questions received were health related [3].

Gillaspy [4] cites seven trends or events in 2000-2005 that have significantly impacted the delivery of $\mathrm{CHI}$ in all settings-but particularly in public libraries:

(i) Increased access to the Internet

(ii) Increased quality of CHI available on the Internet

(iii) Awareness of effect of unhealthy lifestyles in developing serious health problems

(iv) Maturation of consumer health movement

(v) Increase in quality $\mathrm{CHI}$ print resources available

(vi) Emphasis on health literacy

(vii) September 11

Of all of these, the Internet has most transformed how $\mathrm{CHI}$ is distributed and the way that people access health information.
The Pew Internet \& American Life Project's 2007 survey "How people use the internet, libraries, and government agencies when they need help" [5] looked at where people went when they faced complex problems. Forty-five percent of those surveyed were dealing with a serious health problem: $58 \%$ used the Internet for help and $13 \%$ went to the public library for assistance.

The 2007 Ipsos Canadian Inter@ctive Reid Report found that $85 \%$ of Canadians have access to the Internet [6]. Although health was not the most frequent topic searched, it accounted for a large number of searches performed by consumers.

Another continuing trend cited in a recent presentation at the Canadian Health Libraries Association Conference [7] is a growing expectation for consumers to be informed about their health, driven by government, manufacturers, insurers, and workplaces. For example, Wal-Mart has considered discouraging unhealthy people from applying for work by including some physical activity in all jobs [8]. A UK advocacy group emphasizes that health care starts with selfcare, going as far as stating that this is a duty of citizenship. A 2007 New England Journal of Medicine article looked at what responsibilities should be included in a patient's charter of health responsibilities and examined how initiatives in Scotland, Germany, and the United States dealt with the ethical questions that it raised [9].

The Internet has been touted as a vehicle for increased self-management; however, the amount of health information available on the Internet has also been shown to be overwhelming and anxiety-provoking. Despite the patientperceived benefits of bringing Internet health information into medical consultations, family physicians in a study at St. Michael's Hospital in Toronto believed that Internet information generated patient misinformation, leading to con- 
fusion, distress, or an inclination towards detrimental selfdiagnosis and/or self-treatment [10]. CHI librarians have responded to this problem by providing guidance (often oneon-one or group training sessions) to assist consumers in locating reliable health information and developing critical skills in evaluating the health information resources that they find on the Internet.

\section{Public libraries as providers of consumer health information}

Public libraries are often the first point of access for people seeking health information. Particularly in the preInternet era, consumers went to public libraries that they saw as nonthreatening, neutral, and inexpensive sources of health information. However, there were barriers to public libraries taking on a larger role at this time. In the Ontario public library study, reference librarians reported that the major problems that they experienced in providing health information were incomplete or unclear queries from consumers, lack of adequate and appropriate sources in library collections, and their own reluctance to provide health information for fear of being perceived as giving medical advice and interpretation. Many of these points still hold true for public libraries in 2008.

\section{United States}

The provision of health information by public libraries is much more prevalent in the US, due much in part to the funding that is available. Library Services and Construction Act Grants and/or Library Service and Technology Grants [11] have provided significant funding for heath information services in public libraries. The National Library of Medicine (NLM) - the world's largest medical library-changed its mission statement in 1999 to include health information for the public [12]; funding was made available and led to many partnerships of public and health sciences libraries. A search of the National Network of Libraries of Medicine database, imported from NLM's Outreach Consumer Health Database on 6 June 2008, found 1478 records [13]. The majority of recent grants were to improve access to electronic health information. One example is a grant for approximately US\$38 000 that the Crandall Public Library in New York received to increase accessibility to online $\mathrm{CHI}$ for public librarians by providing training on consumer health online resources to 120 librarians in six counties. Grants are also available to assist public libraries in providing health information services to targeted populations, such as African Americans and Hispanic Americans. Another area is health literacy because the majority of health information materials are not written at the optimum accessibility level of grades 2-4.

Only a small percentage of the 16000 US public libraries have the funding and resources to establish a separate $\mathrm{CHI}$ centre [14]. A survey of the Web sites of major US city public library Web sites by IntelliSearch, the Toronto Public Library's fee-based service, only yielded the New York Public Library's Healthinfo service (http://www.nypl.org/health). The health information center is open 7 days a week for 64 hours.

A number of CHI services are partnerships between the public library and a health sciences library but are difficult to locate by checking the public library's Web site. For example, CHIPS (Consumer Health Information Program and Services) is sponsored by the County of Los Angeles Public Library and the Los Angeles County Harbor - UCLA Medical Center Library and is open 6 days a week for 52 hours. Many US public libraries collaborate in the "Go Local" programs with medical and academic libraries, as well as local health associations such as Georgia Health Go Local [15]. Approximately 20 states have complete Go Local coverage, with the remaining having basic coverage via local hospitals. Grants also fund training sessions for public librarians (e.g., a workshop on drug information for the public library being taught by librarians at the Albany College of Pharmacy on 24 June 2008).

Notable examples of successful CHI services in US public libraries are the following:

(i) Wheaton Public Library in Maryland, funded through a Library Services and Construction Act Grant and Montgomery County

(ii) New York Public Library's Healthinfo service

(iii) New Hanover County Public Library

These libraries were also featured among the profile of 12 innovative CHI libraries in the last edition of the most essential resource for those working in the area of CHI: Alan Rees' Consumer Health Information Sourcebook [16]. The Consumer Health Information Service at the Toronto Public Library is the only Canadian service listed.

\section{Canada}

In Canada, a number of public libraries provide links to health information on their Web sites (Halifax, London, Vaughan, Windsor, Mississauga), but only the Toronto Public Library and Kitchener Public Library advertise a walk-in service.

The Mississauga Public Library has consumer health information resources, but you can only find this by clicking "central library" and "sciences department." The HealthLink service at the Kitchener Public Library, established in 2001, can be found by clicking "for your information," "for your health," and then "HealthLink" or "health sites." This service is open during the same hours as the main library. A number of public libraries have health information guides on their Web sites, such as the Edmonton Public Library (http://www.epl.ca/EPLMasterHealth.cfm). Although the Ottawa Public Library has a consumer health collection and health guides, this is not apparent from their Web site; the only way to locate the guides is via the site map (InfoGuides).

In some provinces, public libraries provide provincial-wide service to at least one health database. For example, Newfoundland and Labrador public libraries have a page listing electronic resources that include EBSCO's Health Source database (http://www.nlpubliclibraries.ca/php/eresources.php). Nova Scotia has a health network that is provided through the cooperative efforts of public libraries, health sciences libraries, the Nova Scotia Provincial Library (Department of Education), several health-related organizations, and a number of departments of Dalhousie University (http://www. nshealthnetwork.ca/index.cfm). The portal links to a number of resources, such as directories with information about health-related organizations in Nova Scotia, information writ- 
ten by Nova Scotia health care providers, links to reputable health information sites, access to the Health and Wellness Resource Center, links to databases of libraries in Nova Scotia that provide health information, and an e-mail "Ask a Librarian" service to answer information queries from the public.

The Consumer Health Information Providers Group is a voluntary association of persons in Canada who share an interest in the provision of health information to the general public. The spring 2008 newsletter featured six public libraries that provide some level of health information for consumers: Kitchener, Toronto, Mississauga, Hamilton, Ottawa, and Edmonton (http://www.chla-absc.ca/chipig/Newsletter/ Newsletter2008May.pdf).

In summary, only two public libraries in Canada were identified as having separate consumer health information walk-in services; most public libraries provide access to health databases or produce health information guides. The majority of CHI services in Canada are hospital-based, relying on volunteers in order to maintain a walk-in service, or are "virtual" services.

\section{References}

1. Murray S. Developing a consumer health information service: a practical guide. Toronto: Metropolitan Toronto Reference Library, Consumer Health Information Service; 1995.

2. Marshall JG, Sewards C, Dilworth EL. Health information services in Ontario public libraries. Canadian Library Journal. 1991;48(1):37-44.

3. Wood FB,Lyon B, Schell MB, Kitendaugh P, Cid VH, Siegel ER. Public library consumer health information pilot project: results of a National Library of Medicine evaluation. Bull Med Libr Assoc. 2000;88(4):314-22.

4. Gillaspy ML. Factors affecting the provision of consumer health information in public libraries: the last five years. $\mathrm{Libr}$ Trends. 2005;53(3):480-95.

5. PEW Internet \& American Life Project. How people use the internet, libraries, and government agencies when they need help. 2007 Dec 30. Available from http://www.pewinternet. org/pdfs/Pew_UI_LibrariesReport.pdf.

6. 2007 Ipsos Canadian Inter@ctive Reid Report. Available from http://www.ipsos.ca/pdf/ipsos_interactiveReidReport.pdf.

7. Steinbrook R. Imposing personal responsibility for health. $N$ Eng J Med. 2006 Aug 24;355(8):753-6. Available from http://content.nejm.org/cgi/content/full/355/8/753.

8. DiCarlo L, Sander EC, Burdett S, Harris R. Consumer health information in public libraries: a six-country comparison. London, Ont.: Faculty of Information and Media Studies, University of Western Ontario. Presentation at the Canadian Health Libraries Association Conference, 28 May 2008.

9. Schmidt H. Patients' charters and health responsibilities. BMJ. 2007;335:1187-9. Available from http://www.bmj.com/cgi/ content/full/335/7631/1187.

10. Ahmad F, Hudak PL, Bercovitz K, Hollenberg E, Levinson W. Are physicians ready for patients with Internet-based health information? J Med Internet Res. 2006;8(3):e22. Available from http://www.jmir.org/2006/3/e22.

11. Institute of Museum and Library Services (US). Available grants by institution. Available from http://www.imls.gov/ applicants/institution.shtm.

12. National Network of Libraries of Medicine (US). NN/LM projects database [accessed 2008 June 8]. Available from http://nnlm.gov/funding/database.html.

13. Mays TL, editor. Consumer health issues, trends, and research: part 1. strategic strides toward a better future. Libr Trends. 2004;53(2):265-267.

14. Chobot M. The challenge of providing consumer health information services in public libraries. Washington, D.C.: American Association for the Advancement of Science; 2004. Available from http://www.healthlit.org/pdfs/AAASFINAL.pdf.

15. National Library of Medicine and National Institutes of Health (US). MedlinePlus go Local. Available from http://www.nlm. nih.gov/medlineplus/golocal/index.html.

16. Flake D. Consumer health information in action: profiles of 12 innovative libraries. In: Rees AM, editor. Consumer health information source book. 7th ed. Westport, Conn.: Greenwood Publishing; 2003. p. 231-74. 